\title{
Population dynamics of Excirolana armata (Isopoda: Cirolanidae) in Buenos Aires beaches, Argentina
}

\author{
G. A. Thompson ${ }^{1,2}$ \& M. Sánchez de Bock ${ }^{1}$ \\ 1 Departamento de Ecología, Genética y Evolución, Facultad de Ciencias Exactas y Naturales, Universidad de Buenos \\ Aires, C1428EHA, Buenos Aires, Argentina; gustavo@ege.fcen.uba.ar \\ 2 Fundación Aquamarina, Del Sauce 748, Pinamar, Buenos Aires, Argentina
}

Received 30-IX-2005. Corrected 25-IV-2006. Accepted 16-III-2007.

\begin{abstract}
The population dynamics and structure of the cirolanid isopod Excirolana armata were studied from January 2004 through March 2005 in three sandy beaches of Buenos Aires Province (Argentina). Beaches with different types of anthropogenic influences were selected. The von Bertalanffy's growth function parameters were determined for each population. There was a marked fluctuation in growth, with lowest rates in late autumn and winter. The isopod population of the beach exposed to the highest degree of anthropogenic erosion had the lowest and most stable values of abundance and biomass, the highest mortality rate and the shortest life span. Temporal fluctuations of the allometric coefficient of the length-dry weight relationship indicated a cycling pattern, with lowest values during the autumn-winter period and peak values in the summer. Females predominated in the populations due to the short duration of the reproductive season. Argentine and Uruguayan populations showed similar growth performance indices, but differed in their abundance and biomass values, probably as a response to variations in beach morphodynamics and biological interactions. Rev. Biol. Trop. 55 (Suppl. 1): 131-140. Epub 2007 June, 29.
\end{abstract}

Key words: cirolanids, population dynamics, sandy beaches, Excirolana armata

The supra-littoral and intertidal zones of sandy beaches around the world are mostly dominated by cirolanid isopods of the genus Excirolana (Wendt and McLachlan 1985, Defeo et al. 1992, 1997). This genus is ovoviviparous and has no larval dispersal (Klapow 1970). Excirolana armata Dana (1853) extends from $23^{\circ} \mathrm{S}$ (Rio de Janeiro State - Brazil) to $42^{\circ} \mathrm{S}$ (Chubut Province - Argentina) (Veloso et al. 2003, Ribetti and Roccatagliata 2006) and inhabits intertidal levels of dissipative and intermediate beaches characterized by fine sand and gentle slopes (Defeo et al. 1997, Giménez and Yannicelli 1997). Ribetti and Roccatagliata (in press) have recently redescribed E. armata for Argentina, and concluded that Cirolana argentina is a junior synonym of E. armata. This species is dominant in terms of numbers in the intertidal-supralittoral zones of sandy beaches of the province of Buenos Aires (Thompson et al. 2005). The present study analyzed for the first time populations of E. armata in Argentina. Three temperate sandy beaches with different types of anthropogenic influences (urbanization, forestation) that may affect isopod population dynamics and structure were selected. In addition, we compare our results to previous data on Uruguayan populations of this genus (de Alava and Defeo 1991, Defeo et al. 1997, Lercari and Defeo 2003).

\section{MATERIALS AND METHODS}

Three exposed microtidal sandy beaches of Buenos Aires Province, Argentina, were considered: Las Toninas (LT, 36 $27^{\circ}$ ' S 56 $41^{\circ}$ ' W), Mar del Tuyú (MT, 36³3' S 56²41’ W) 
and Aguas Verdes (AV, 36 38' S 56 41' W). Las Toninas beach (1 km north of Las Toninas town), which had a dune level and a foredune partially covered by vegetation (mainly native Spartina spp.), was the site least impacted by human activities. Mar del Tuyú beach was affected by urbanization and by moderate touristic activities during the summer months, and its dune line has been cut by man-made structures (buildings and beach accesses). Finally, Aguas Verdes beach (1 km north of Aguas Verdes town) was characterized by a dune line and a foredune covered and fixed by a Tamarix gallica (tamarisco) forestation. Transverse beach profiles were surveyed in each beach to establish the degree of man-induced erosion, according to the erosive model developed by Marcomini and López (1997), which grades erosion from 0 (none) to 5 (very high). Physical variables were registered and a two-factor ANOVA without replication was carried out to determine the dependence of each variable on beach and sampling period. The Tukey's non-additivity test was performed before each ANOVA.

Samples of isopods were collected bimonthly from January 2004 through March 2005. On each sampling period (occasion) and beach, three transects were set up perpendicularly to the shoreline and separated $6 \mathrm{~m}$ between each other. Samples of each transect were taken every $6 \mathrm{~m}$ using a plastic cylinder (27 $\mathrm{cm}$ in diameter and $40 \mathrm{~cm}$ deep), from the base of the dunes to the lower limit of the swash zone, considered as the minimum tidal advance. More than 36 samples were taken per beach and occasion. Organisms retained after sieving through a $0.8-\mathrm{mm}$ mesh were fixed in $5 \%$ formalin and preserved in $70 \%$ alcohol. Isopods were measured to the nearest $0.1 \mathrm{~mm}$ from the tip of the cephalon to the end of the telson (Dexter 1977), dried at $60{ }^{\circ} \mathrm{C}$ until constant weight to the nearest $0.0001 \mathrm{~g}$. Population densities were estimated as the number (or biomass) of individuals per strip-transect (IST: individuals $\mathrm{m}^{-1}$, BST: $\mathrm{g} \mathrm{m}^{-1}$; Defeo 1996). A two-factor ANOVA design was used to determine the dependence of isopod abundance (or biomass) on beach and occasion. The Tukey's HSD multiple comparison test was used $a$ posteriori to assess the significance of differences.

The length-frequency distributions (LFDs) for each beach were grouped into 1-mm size-classes and compared by the nonparametric test of Kolmogorov-Smirnov (Sokal and Rohlf 1995). The LFDs were used to estimate the growth parameters by two methods sequentially applied: (1) Powell-Wetherall and (2) Electronic Length Frequency Analysis (ELEFAN), both of them incorporated in the FiSAT software (Gayanilo and Pauly 1997). The first one was used to provide an initial estimate of the asymptotic length $L_{\infty}$ that was used to fit the generalized von Bertalanffy growth function (VBGF)

$$
\left.L_{t}=L_{\infty}\left[1-\mathrm{e}^{(-\mathrm{K}(\mathrm{t}-\mathrm{t}} \mathrm{O}\right)-(\mathrm{C}(\mathrm{K} / 2 \pi) \sin (2 \pi(\mathrm{t}-\mathrm{WP})))\right]
$$

where $K$ = curvature parameter, $C=$ amplitude of the seasonal growth oscillation (which varies between zero and one, with zero indicating the lack of summer-winter differences in growth), $W P=$ winter point (i.e., time expressed as a decimal fraction of the year when the growth was slowest), and $t_{0}=$ theoretical age of an isopod at the zero length. The $R n$ index evaluates the goodness of the estimated VBGF. The growth parameters $L_{\infty}$ and $K$ were expected to be inversely correlated, therefore the growth index phi prime $\phi^{\prime}=2 \log _{10}\left(L_{\infty}\right)+\log _{10}(K)$ was used to measure growth performance (Pauly and Munro 1984). Mortality was calculated by means of the instantaneous rate of natural mortality (M), estimated using the length-converted catch curve (LCCC) through the equation given by Pauly et al. (1995) for species with seasonal oscillation growth (i.e., when $\mathrm{C}>0$ ). This method used the VBGF parameters to plot the $\ln (F /$ $\mathrm{d} t$ ) against $t$; where for each length class: $F=$ frequency of specimens, $\mathrm{d} t=$ time needed by the isopod to grow, and $t=$ relative age of the isopod. The negative slope of the resulting linear regression line through the data points gave the $M$ value. The life span $\left(t_{\text {max }}\right)$ was derived from Hoenig's (1983) model: ln (Z): 1.44 - 0.984.ln 
$\left(t_{\text {max }}\right)$, where $\mathrm{Z}$ (total mortality) was equal to $\mathrm{M}$ due to the absence of fishing mortality.

Isopods were classified as juveniles (up to $4 \mathrm{~mm}$ and with no visible sexual characters) and adults (males, females and ovigerous females). The proportion of females to males was tested by the $X^{2}$-test. The length-dry weight $(L-W)$ relationship was estimated separately by sex and beach, using the logarithmic transformation $\log W=\log \mathrm{a}+\mathrm{b} \log L$, and the $95 \%$ confidence interval for the slope (b) or allometric coefficient. Since the assumption of homogeneity of slopes of dependent variable-covariate was not met (parallelism test, $\mathrm{p}<10^{-27}$ ), the analysis of covariance (ANCOVA) could not be used to evaluate differences in the $L-W$ relationship. Instead, Zar's (1999) procedure was used to test for slope homogeneity (i.e., equality) among sexes, beaches and occasions. When significant differences were detected, the Tukey's HSD multiple comparison test was applied to determine temporal or spatial fluctuations of the $b$ value.

\section{RESULTS}

The transverse profile of LT beach was mainly convex, whereas AV profile presented a rather linear configuration and MT showed a concave profile, which corresponded to low, moderate-high and very high degree of maninduced erosion, respectively (grades 2, 3-4 and 5 respectively of the model by Marcomini and Lopez 1997). In spite of the different degrees of human impact represented by the sandy beaches studied, the ANOVA performed on their physical features indicated similar values in all three beaches in every occasion and did not show significant fluctuations during the sampling period (Table 1). The three beaches were characterized by fine sands, moderately well sorted, gentle slopes and fluctuating widths (between 50 and $110 \mathrm{~m}$ ) with wide surf zones. According to the Dean's parameter values (Table 1) all three beaches should be included in the intermediate morphodynamic state almost all the year round.

A total of 3005 specimens were collected. Abundance and biomass values oscillated throughout the sampling period in AV and LT (Fig. 1). This situation resulted in a significant interaction between the factors "beach" and "occasion" in the ANOVAs (Table 2). Isopod concentration peaked significantly (Tukey HSD test, $\mathrm{p}<0.05$ ) in September in $\mathrm{AV}$, both in numbers (5 083 \pm 1825 ind. $\left.\mathrm{m}^{-1}\right)$ and biomass $\left(16 \pm 6 \mathrm{~g} \mathrm{~m}^{-1}\right)$, and during

TABLE 1

Characterization of physical attributes of Las Toninas (LT), Mar del Tuyú (MT) and Aguas Verdes (AV) beaches, and significance of two-way ANOVA, for beach $\left(p_{1}\right)$ and occasion $\left(p_{2}\right)$ factors.

\begin{tabular}{|c|c|c|c|c|}
\hline Beaches & \multicolumn{4}{|c|}{ ANOVA } \\
\hline \multirow[t]{2}{*}{ Beach features } & LT & MT & $\mathrm{AV}$ & \\
\hline & Mean \pm SD & Mean \pm SD & Mean \pm SD & $\mathrm{p}_{1}-\mathrm{p}_{2}$ \\
\hline Beach width (m) & $96 \pm 16$ & $80 \pm 13$ & $78 \pm 15$ & $0.22-0.36$ \\
\hline Intertidal beach width (m) & $54 \pm 17$ & $58 \pm 18$ & $54 \pm 15$ & $0.93-0.35$ \\
\hline Grain size (phi) a $^{a}$ & $1.98 \pm 0.22$ & $2.15 \pm 0.17$ & $2.04 \pm 0.29$ & $0.49-0.23$ \\
\hline Sorting (phi) ${ }^{\mathrm{a}}$ & $0.68 \pm 0.28$ & $0.62 \pm 0.23$ & $0.72 \pm 0.22$ & $0.73-014$ \\
\hline Beach face slope (\%) & $1.58 \pm 0.57$ & $1.19 \pm 0.33$ & $1.46 \pm 0.38$ & $0.55-0.27$ \\
\hline Dean parameter $(\Omega)^{\mathrm{b}}$ & $2.95 \pm 1.70$ & $3.26 \pm 1.16$ & $3.09 \pm 0.93$ & $0.88-0.06$ \\
\hline
\end{tabular}

${ }^{a}$ Methodology as in Larson et al. (1997)

${ }^{\mathrm{b}} \Omega=$ breaker height / sand fall velocity $\bullet$ wave period (Short and Wright 1983) 

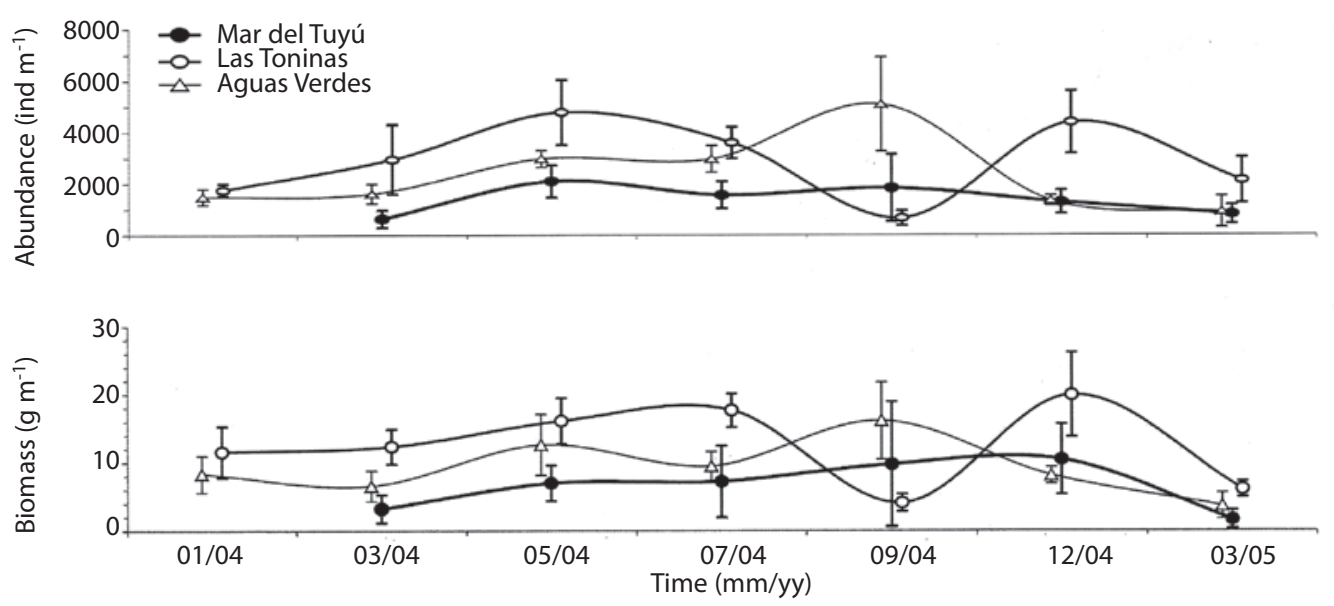

Fig. 1. Abundance (mean \pm SD) of Excirolana armata during the study period for each beach.

TABLE 2

Two-factor ANOVA (beach and time) of abundance (IST) and biomass (BST) of Excirolana armata.

\begin{tabular}{lccccc} 
& \multicolumn{2}{c}{ IST } & \multicolumn{2}{c}{ BST } \\
& F & p & F & p \\
Beach & 18.4 & $<10^{-6}$ & 6.6 & $<10^{-4}$ \\
Occasions & 6.3 & $<10^{-4}$ & 10.8 & $<10^{-4}$ \\
Beach x Occasions & 7.1 & $<10^{-6}$ & 3.6 & $<10^{-3}$
\end{tabular}

December in LT (4 390 \pm 1206 ind. $\mathrm{m}^{-1}$ and 20 $\pm 6 \mathrm{~g} \mathrm{~m}^{-1}$, respectively) (Fig. 1). On the other hand, abundance and biomass in MT showed the lowest and most stable values during the entire sampling period (Fig. 1).

The comparison of the length-frequency distributions among the three locations indicated similar distributions in AV and LT throughout the year, while both localities differed from MT in March, September and December (Kolmogorov-Smirnov test, $\mathrm{p}<0.05$, Fig. 2). Table 3 shows the VBGF parameters for all three sampling locations, whereas figure 3 illustrates the growth curve resulting from the application of the ELEFAN routine to the data of each beach. The instantaneous rate of natural mortality was highest in the urbanized beach (MT), which resulted in the shortest life span for this population. The largest asymptotic length and the lowest curvature parameter $(K)$ were recorded in the southern forested beach
(AV), while the inverse was true for the northern beach (LT). However, the growth performance index $\left(\phi^{\prime}\right)$ was very similar for the three beaches. The parameter $C$ indicated an intense intra-annual oscillation in growth, and the WP denoted minimum growth between July and September in all three locations.

The female:male ratio differed significantly from the expected 1:1 (Yates corrected $X^{2}$-test: $\mathrm{p}<0.05$ ) for each locality during most of the year, except in July. The overall mean $( \pm$ SD) female:male ratio was $2.04 \pm 0.24$ in MT, $2.02 \pm 1.00$ in AV and $2.01 \pm 1.18$ in LT. A single -few months long- reproductive pulse was observed: ovigerous females were registered between December and March with their highest concentrations in February (17 to $36 \%$ of females) in the three localities. Juveniles were present from February through May in LT and MT and from January through July in AV, with peak concentrations in March in MT and AV 


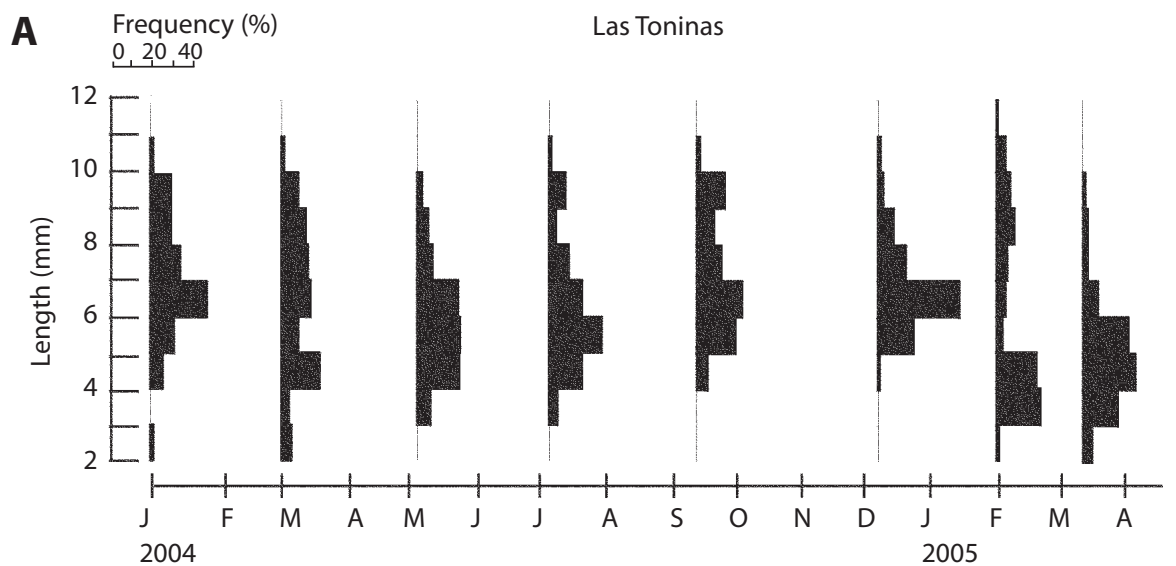

B $\quad \begin{aligned} & \text { Frequency }(\%) \quad \text { Mar del Tuyú } \\ & 0,20,40\end{aligned}$

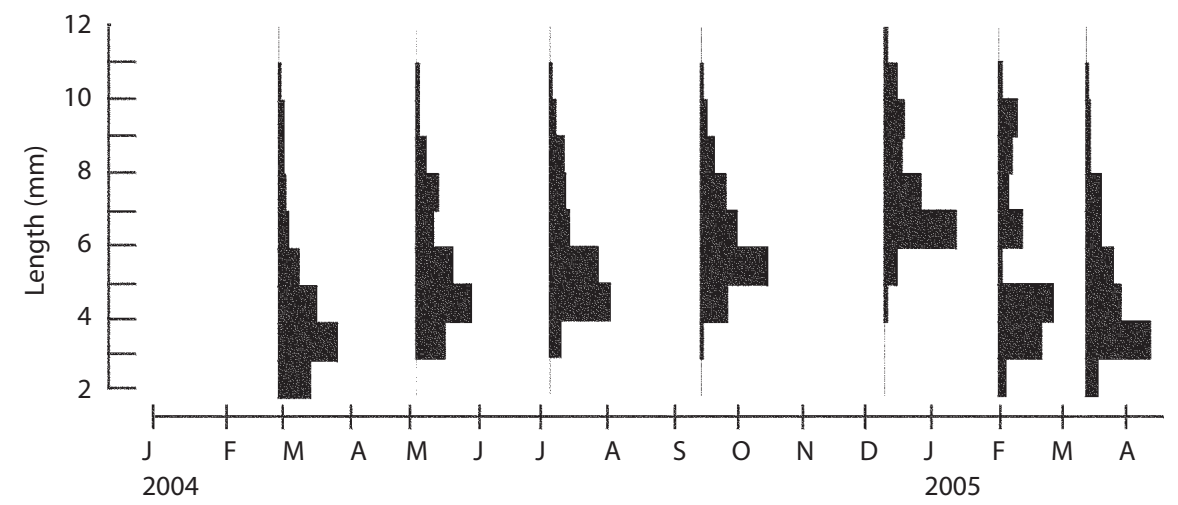

C Frequency (\%) Aguas Verdes

$0,20,40$

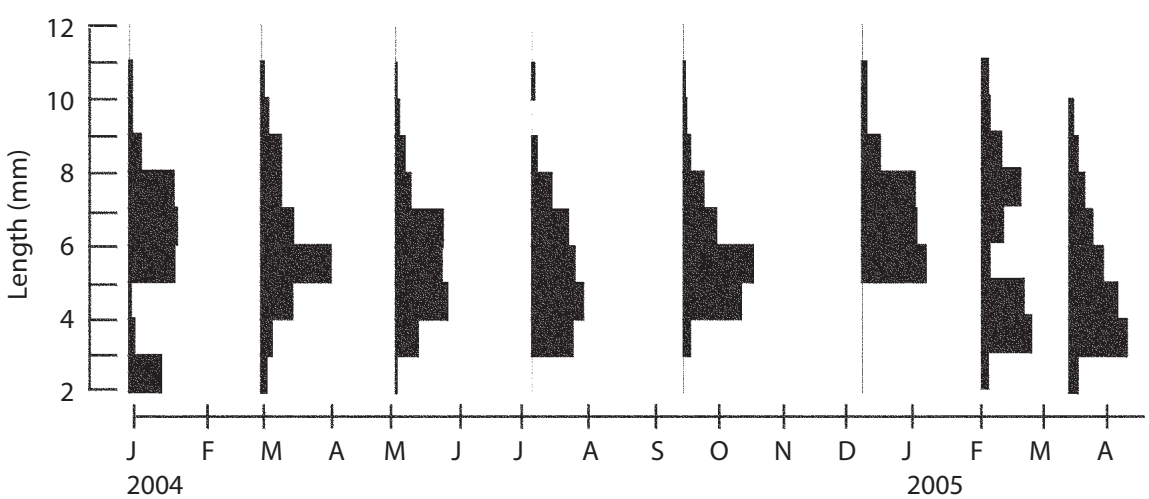

Fig. 2. Length-frequency distribution of the cirolanids during the sampling period for A. Las Toninas, B. Mar del Tuyú, and C. Aguas Verdes. 
TABLE 3

Growth parameters of Excirolana armata for Las Toninas (LT), Mar del Túyu (MT) and Aguas Verdes (AV) estimated by ELEFAN method and FiSAT Program.

\begin{tabular}{lccc} 
& \multicolumn{3}{c}{ Beaches } \\
Parameters & LT & MT & AV \\
$L_{\infty}(\mathrm{mm})$ & 11.52 & 12.11 & 12.20 \\
$K\left(\mathrm{y}^{-1}\right)$ & 0.77 & 0.69 & 0.52 \\
$\mathrm{C}$ & 0.88 & 0.97 & 0.96 \\
$\mathrm{WP}$ & 0.6 & 0.7 & 0.5 \\
$t_{0}(\mathrm{y})$ & -0.32 & -0.34 & -0.42 \\
$\phi^{\prime}$ & 2.0 & 2.0 & 1.9 \\
$M\left(\mathrm{y}^{-1}\right)$ & 1.33 & 1.81 & 1.52 \\
$t_{\text {max }}(\mathrm{y})$ & 3.2 & 2.4 & 2.8 \\
$\mathrm{Rn}$ & 0.307 & 0.461 & 0.241
\end{tabular}

and in February in LT (Fig. 4). Significant linear regressions between length and dry weight were found in every occasion $\left(0.81<\mathrm{R}^{2}<0.96\right)$. The estimated values of the allometric coefficient b ranged from 2.85 to 3.72 . This coefficient did not differ significantly between males and females $(\mathrm{p}>0.05)$; therefore, the sex factor was not considered in further analyses, so that all data were pooled for each beach (Fig. 5). Differences in the coefficient $b$ among locations were not detected ( $>>0.05)$, except in February 2005, when the value in AV was significantly higher, and in March 2005 when b was significantly lower in MT. The temporal fluctuations in the b value indicated similar patterns in all three locations, with higher values during the summer (January and February), which differed significantly $(\mathrm{p}<0.05)$ from the lower values recorded during the autumnwinter period (March-July) (Fig. 5).

\section{DISCUSSION}

The beach influenced by the highest maninduced erosion, Mar del Tuyú, showed the lowest and least fluctuating abundance values of E. armata. On the other hand, the highest mortality rate and the shortest life span characterized this cirolanid population. Conversely, the highest abundance and biomass values, the lowest mortality rate and longest life span corresponded to the beach having the lowest degree of anthropogenic erosion, Las Toninas. The observed tendency is in agreement with Defeo and McLachlan's (2005) suggestion about the negative effects of human activities (concerning man-made structures) resulting in habitat unsuitability, which is a possible modifying factor of mortality rates and density values.

The $\phi$ ' index values registered suggest that individual growth performances of $E$. armata were similar in the three beaches, in spite of a slight north-south decrease of the curvature parameter $(K)$ values and an increase in the asymptotic length $\left(L_{\infty}\right)$ values. E. armata showed marked growth fluctuations, with slow growth rates during the late austral autumn and winter, and faster growth rates from spring onwards. A similar pattern has already been reported for this species (Gianuca 1985, de Alava and Defeo 1991) and for Excirolana braziliensis (Cardoso and Defeo 2004) in southern Brazilian and Uruguayan beaches ( 32-34 $\left.{ }^{\circ} \mathrm{S}\right)$. This seasonal oscillation of growth rates may be ascribed to the high intra-annual variation in the surf seawater temperature (Cardoso and Defeo 2004), which was approximately $12{ }^{\circ} \mathrm{C}$ in the three studied localities. Temperature oscillations limited the reproductive season to three to four months per year, which was reflected in the single peak of juveniles recorded in these beaches. This pattern differs from the one of tropical populations where reproduction occurs year-round. The predominance of females in the population might be a consequence of the short duration of the reproductive season registered not only in this study, but also for E. braziliensis in temperate beaches (Cardoso and Defeo 2003). The reproductive events (spawning season, breeding period and release of juveniles) of the herein studied populations of E. armata and those of the Uruguayan ones (Barra del Chuy beach, de Alava and Defeo 1991) had a similar duration, but in the former they occurred earlier in the year. This trait, which has also been reflected in the significant increase of the allometric coefficient of the 
A Las Toninas

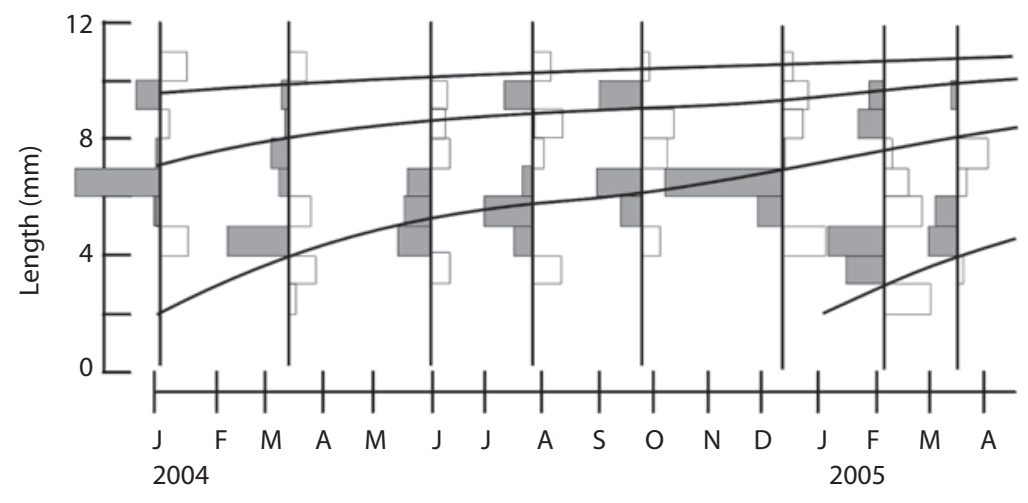

B Mar del Tuyú

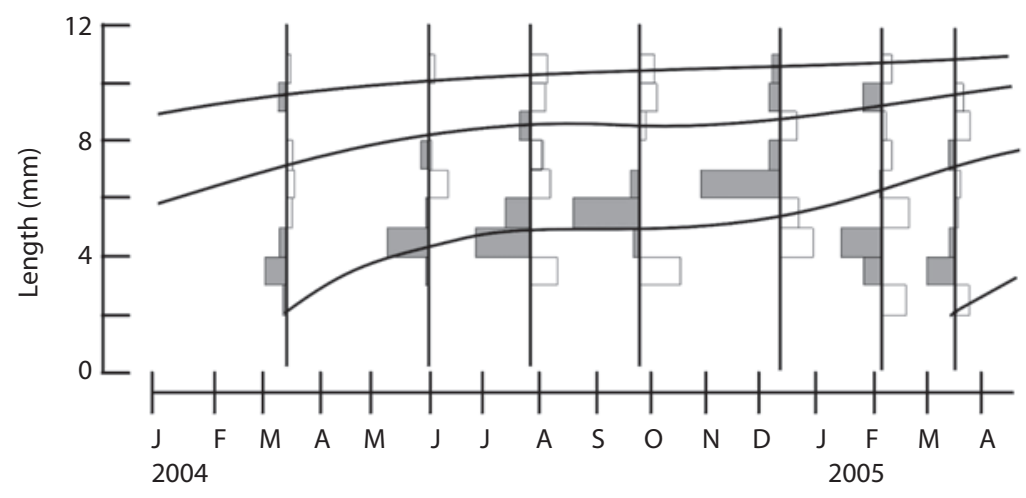

C Aguas Verdes

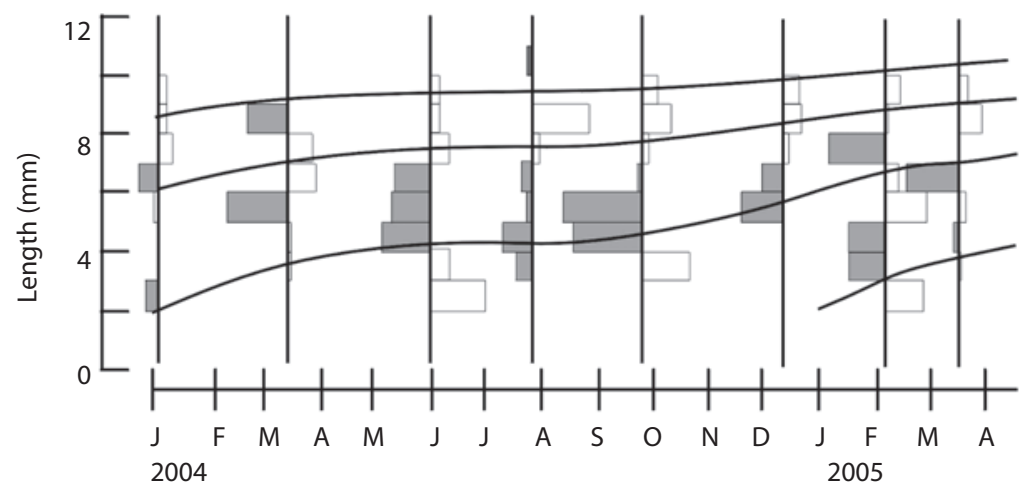

Fig. 3. Restructured length-frequency distribution of the cirolanids during the sampling period for A. Las Toninas, B. Mar del Tuyú and C. Aguas Verdes; lines denote suggested growth curves as indicated by the VBGF analysis performed. 


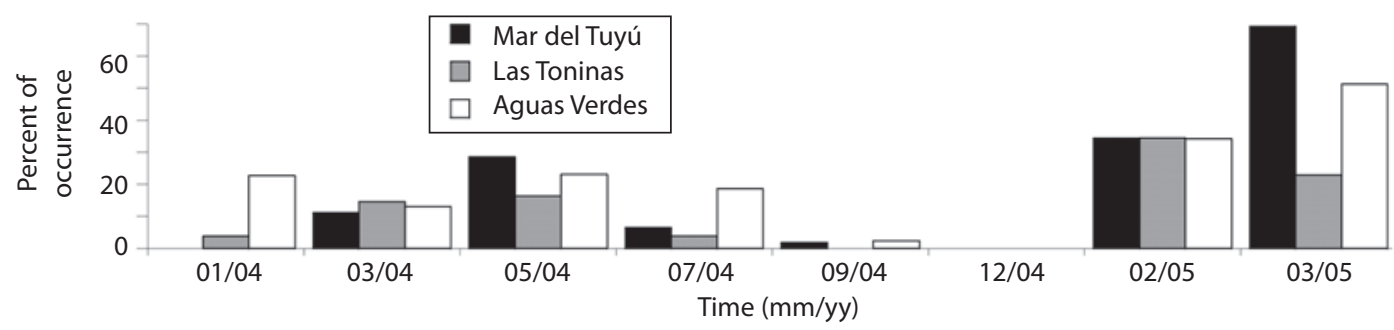

Fig. 4. Percent of occurrence of juveniles of Excirolana armata during the sampling period for each beach.

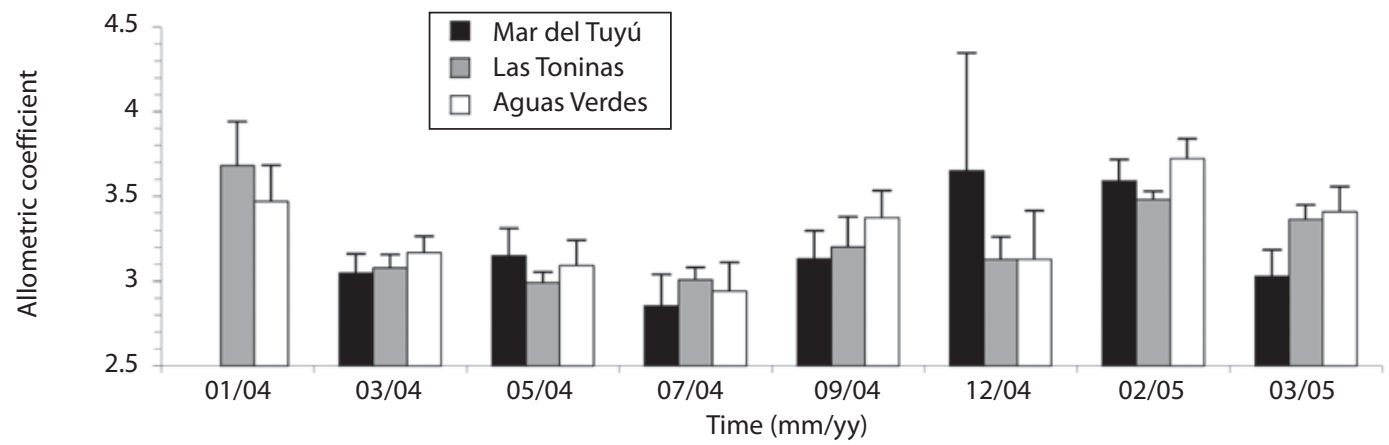

Fig. 5. Allometric coefficient of length-dry weight relationship and $95 \%$ confidence interval (only upper limit draw) for Excirolana armata during the sampling period for each beach.

L-W relationship in the warm season, ensured the occurrence of the new brood mainly in late summer and early autumn, thus avoiding the lower winter seawater temperatures (as low as $9.8^{\circ} \mathrm{C}$ ). In the Uruguayan population, the release of juveniles occurs later in the year -late autumn and early winter-, probably due to the locally higher minimum temperatures $\left(11^{\circ} \mathrm{C}\right.$, de Alava and Defeo 1991).

The length-frequency distribution showed only one modal component for AV and MT and only two modal components for LT (Fig. 2 ), instead of the three expected according to the life span values (Table 3). This discrepancy might be related to the occurrence of predators that probably affected unevenly the different stages of the isopod life cycle (de Alava and Defeo 1991). At least eight benthic and bottom dwelling coastal fishes are known predators of marine isopods in the Argentine coast (Cousseau and Perrotta 2000). In particular, cirolanid isopods have been detected in the stomach content of Acanthistius brasilianus ('mero'), Urophycis brasiliensis ('brótola') and
Trachinotus marginatus ('pámpano')(Goldstein 1986, Goldstein and Cousseau 1987, Rodrigues Cunha 1989).

Although growth performance values determined in our study were similar to the ones of Uruguayan populations of E. armata ( $\phi^{\prime}=1.99$ and 1.96 for Barra del Chuy and La Coronilla, respectively), mean abundance values registered for MT, LT and AV (38 \pm 21 ; $60 \pm 44$; $65 \pm 49$ ind. $\mathrm{m}^{-2}$, respectively) were notably lower than the ones reported for the Uruguayan beaches Barra del Chuy and La Coronilla (around $280 \pm 80$ ind. $\mathrm{m}^{-2}$, Defeo et al. 1997). Variations in density may be ascribed to differences in beach morphodynamics or to biological interactions (competition) (Defeo et al. 2003, Defeo and McLachlan 2005). The beaches studied by us are harsher environments than Barra del Chuy beach (dissipative state; Defeo and Gómez 2005), which might be forcing local populations to allocate more energy in maintenance rather than in growth and/or reproduction (Defeo and Martínez 2003). Intraspecific competition 
could not be established in this work, neither as a negative correlation between ranked mean density and individual isopod mean length, nor as segregation by length groups (data not shown). On the other hand, the interspecific interaction between E. armata and E. braziliensis was dismissed, due to the total absence of the latter species in the three beaches throughout the sampling period. Besides, both present and previous studies of E. armata populations did not consider interannual variations in abundance and VBGF parameters, therefore the variability due to stochastic elements could not be removed from the data.

In summary, population parameters of $E$. armata such as abundance, biomass, mortality rate and life span seem to be related to the degree of man-induced erosion, at least at the local level. In addition, at the mesoscale level, the physical environment or the biological interactions seem to influence abundance values. To be able to establish biogeographic patterns and the possible use of E. armata as an indicator species of environmental human impact, further long-term studies regarding population dynamics are needed along its entire distribution area (Brazil, Uruguay and Argentina), throughout a wide spectrum of man-made perturbations, beach morphodynamic states and biological conditions.

\section{ACKNOWLEDGMENTS}

We are especially grateful to O. Defeo for the important suggestions on the manuscript. We express our gratitude to colleagues and friends for field assistance. This work was supported in part by funds from the PADI Foundation and Fundación Aquamarina.

\section{RESUMEN}

Se estudió la dinámica y estructura poblacional de Excirolana armata en tres playas arenosas de la provincia de Buenos Aires (Argentina), de enero de 2004 a marzo de 2005. Se seleccionaron playas sometidas a distintos tipos de influencias antropogénicas. Los parámetros de la función de crecimiento de von Bertalanffy fueron determinados en cada playa. Esta especie mostró una notable fluctuación en su crecimiento, con tasas más bajas a fines de otoño y en invierno. La población de la playa con mayor grado de erosión antropogénica presentó los valores menores y más estables de densidad y biomasa, la más alta tasa de mortalidad y la menor longevidad. Las variaciones temporales del coeficiente alométrico de la relación longitud-peso seco indicaron un patrón cíclico, con los menores valores en otoño-invierno y los mayores en verano. Las hembras predominaron en la población debido a la corta duración de la temporada reproductiva. Las poblaciones argentinas y uruguayas tienen índices similares en el crecimiento, pero difieren en los valores de abundancia y densidad, probablemente como respuesta a variaciones en la morfodinámica de las playas y en las interacciones biológicas.

Palabras clave: cirolánidos, dinámica poblacional, playas arenosas, Excirolana armata

\section{REFERENCES}

Cardoso, R.S. \& O. Defeo. 2003. Geographical patterns in reproductive biology of the Pan-American sandy beach isopod Excirolana braziliensis. Mar. Biol. 143: 573-581.

Cardoso, R.S. \& O. Defeo. 2004. Biogeographic patterns in life history traits of the Pan-American sandy beach isopod Excirolana braziliensis. Estuar. Coast. Shelf Sci. 61: 559-568.

Cousseau M.B. \& R.G. Perrotta. 2000. Peces marinos de Argentina. Biología, distribución, pesca. Instituto Nacional de Investigación y Desarrollo Pesquero, Mar del Plata, Argentina. 167 p.

de Alava, A. \& O. Defeo. 1991. Distributional pattern and population dynamics of Excirolana armata (Isopoda: Cirolanidae) in a Uruguayan sandy beach. Estuar. Coast. Shelf Sci. 33: 433-444.

Defeo, O. 1996. Experimental management of an exploited sandy beach bivalve population. Rev. Chil. Hist. Nat. 69: 605-614.

Defeo, O. \& J. Gómez. 2005. Morphodynamics and habitat safety in sandy beaches: life-history adaptations in a supralittoral amphipod. Mar. Ecol. Prog. Ser. 293: 143-153.

Defeo, O. \& G. Martínez. 2003 The habitat harshness hypothesis revisited: life history of the isopod Excirolana braziliensis in sandy beaches with contrasting morphodynamics. J. Mar. Biol. Ass. UK 83: 331-340. 
Defeo, O. \& A. McLachlan. 2005. Patterns, processes and regulatory mechanisms in sandy beach macrofauna: a multi-scale analysis. Mar. Ecol. Prog. Ser. 295: 1-20.

Defeo, O., E. Jaramillo \& A. Lyonnet. 1992. Community structure and intertidal zonation of the macroinfauna in the Atlantic coast of Uruguay. J. Coast. Res. 8: 830-839.

Defeo, O., D. Lercari \& J. Gómez. 2003. The role of morphodynamics in structuring sandy beach populations and communities: what should be expected? J. Coast. Res. Spec. Iss. 35: 352-362.

Defeo, O., A. Brazeiro, A. de Alava \& G. Riestra. 1997. Is sandy beach macrofauna only physically controlled? Role of substrate and competition in isopods. Estuar. Coast. Shelf Sci. 45: 453-462.

Dexter, D.M. 1977. Natural history of the Pan-American sand beach isopod Excirolana braziliensis (Crustacea: Malacostraca). J. Zool. London 183: 103-109.

Gayanilo, Jr. F.C. \& D. Pauly (eds.). 1997. FAO-ICLARM stock assessment tools (FiSAT): Reference Manual, vol. 8. FAO Comp. Info. Ser. (Fish). 262 p.

Gianuca, N.M. 1985. The ecology of sandy beach in southern Brazil. PhD thesis, University of Southampton, Hampshire, England

Giménez, L. \& B. Yannicelli. 1997. Variability of zonation patterns in temperate microtidal Uruguayan beaches with different morphodynamic types. Mar. Ecol. Prog. Ser. 160: 197-207.

Goldstein, H.E. 1986. Características morfológicas del sistema digestivo y hábitos alimentarios de la brotola (Urophycis brasiliensis) (Pisces, Gadidae). Publ. Com. Téc. Mix. Fr. Mar. 1: 351-368.

Goldstein, H.E. \& M.B. Cousseau. 1987. Estudio sobre el régimen alimentario del mero (Acanthistius brasilianus) y su relación con las características morfométricas del sistema digestivo (Pisces, fam. Serranidae). Rev. Invest. Des. Pesq. 7: 85-103.

Hoenig, J.M. 1983. Empirical use of longevity data to estimate mortality rates. Fish. Bull. US 82: 898-902.

Klapow, L.A. 1970. Ovoviviparity in the genus Excirolana (Crustacea: Isopoda). J. Zool. Lond. 162: 359-369.

Larson, R., A. Morang \& L. Gorman. 1997. Monitoring the coastal environment; Part II: Sediment sampling and geotechnical methods. J. Coast. Res. 13: 308-330.
Lercari, D. \& O. Defeo 2003. Variation of a sandy beach macrobenthic community along a human-induced environmental gradient. Estuar. Coast. Shelf Sci. 58: 17-24.

Marcomini, S.C. \& R.A. López. 1997. Beach profile vulnerability. In: Proceeding Bordomer 97: Coastal Environments Management and Conservation. Actes du colloque 2: 220-231

Pauly, D. \& J.L. Munro. 1984. Once more on growth comparison of fish and invertebrates. ICLARM Fishbyte 2: 21.

Pauly, D., J. Moreau \& N. Abad. 1995. Comparisons of age-structured and length-converted catch curves of brown trout Salmo trutta in two French rivers. Fish. Res. 22: 197-204.

Ribetti, V.L. \& D. Roccatagliata. 2006. Redescription of Excirolana armata (Dana, 1853) and synonymy of Cirolana argentina Giambiagi, 1930 (Crustacea: Isopoda: Cirolanidae) Proc. Biol. Soc. Wash. 119:1-14.

Rodrigues Cunha, L.P. 1989. Aspectos de la bioecología del pámpano (Trachinotus marginatus). VI Simposio Científico, Comisión Técnica Mixta del Frente Marítimo-CUIDAD, Uruguay. p. 14-15.

Short, A.D \& L.D. Wright. 1983. Physical variability of sandy beaches, p 137-144. In A. McLachlan, T. Erasmus (eds.). Sandy Beaches as Ecosystems. W. Junk, The Hague, Netherlands.

Sokal, R.R. \& F.J. Rohlf. 1995. Biometry. The principles and practice of statistics in biological research. Freeman, New York, USA.

Thompson, G., M. Sánchez de Bock \& P. Bordino. 2005. Morfodinámica intermareal y distribución espaciotemporal de la macroinfauna en las playas arenosas del noreste de la provincia de Buenos Aires. Resúmenes XI COLACMAR, Viña del Mar, mayo 2005, Chile.

Veloso, V.G., C.H.S. Caetano \& R.S. Cardoso. 2003. Composition, structure and zonation of intertidal macroinfauna in relation to physical factors in microtidal sandy beaches in Rio de Janeiro state, Brazil. Sci. Mar. 67: 393-402.

Wendt, G.E. \& A. McLachlan. 1985. Zonation and biomass of the intertidal macrofauna along a South African sandy beach. Cah. Biol. Mar. 26: 1-14.

Zar, J.H. 1999. Biostatistical Analysis. Prentice Hall, New Jersey, USA. 